\title{
Strategic Management of HRM Practices and Innovation Performance in the High Tech Fiberglass Sector in Bahrain: Mediating Role of Organizational Innovation
}

\author{
Habil Slade Ogalo \\ Faculty of Business Studies, Arab Open University, Bahrain \\ drhabilslade@aou.org.bh \\ Correspondence: drhabilslade@aou.org.bh
}

Received: 15 ${ }^{\text {th }}$ May 2020; Accepted: 22 ${ }^{\text {nd }}$ July 2020; Published: $1^{\text {st }}$ August 2020

Abstract: Growing use of fiberglass admixture in construction along with automotive industries has escalated demand of fiberglass among the firms and fueling them with the innovational strategy in order to be competitive. Fiberglass businesses being one of the high-tech sectors have to consider many domains. Although, due to the inflexibility of employees, the absence of innovative atmosphere and monopolistic composition, employees are unwilling to be innovative in organizations. The current study argued that strategic management of new HRM practices through enhancing more skillful, talented, committed, motivated can further innovation and innovational employees that helps in higher productivity of the organization. However, to demonstrate this connection is insufficient in terms of empirical evidence. Consequently, the main objective of this investigation to examine role of strategic management of New HRM practices on innovation performance followed by the mediation of organizational innovation. Data has collected from Bahrain's manufacturing sector of fiberglass that came up with significant positive association between the endogenous and exogenous variables.

Keywords: Strategic Management; HRM Practices; Organizational Innovation; Innovation Performance; Technology Organization Environment Theory

\section{Introduction}

Intense globalized competition among manufacturing organizations has been generating challenges that are more innovational. Due to autocratic and anti-competitive power of services suppliers, state and public government have not recognized the compulsion of innovatory policies (Park et al., 2018). Due to substandard HR policies of the incentive system and rewards employees are resistant to behave efficiently that is an alarming situation for firms. The current study argues that the concept of strategic management can significantly help enhance organization`s capability in handling any type and length of tasks. Scholars have underlined that strategic management of businesses can significantly help them to improve their business operations for a greater good (Barney \& Hesterly, 2010).

Habil Slade Ogalo, "Strategic Management of HRM Practices and Innovation Performance in the High Tech Fiberglass Sector in Bahrain: Mediating Role of Organizational Innovation", Annals of Contemporary Developments in Management E HR (ACDMHR), Print ISSN: 2632-7686, Online ISSN: 2632-7694, pp. 43-55, Vol. 2, No. 3, $1^{\text {st }}$ August 2020, Published by International Association of Educators and Researchers (IAER), DOI: 10.33166/ACDMHR.2020.03.001, Available: http://acdmhr.theiaer.org/archive/v2/v2n3/p1.html. 
Although over the past decades, whole world has been surrounded with innovative strategies that lifted up transformation in government organization. State-owned firms are in state of need to perform productively and competently like private sectors. Thus, to complete this government are also striving to implement those innovational strategies that strengthen the innovational performance through employing talented \&skilled personnel, upgraded operating network and finest communication structure (Barney \& Hesterly, 2010). Now a day's innovation has become one of the most significant subjects in fiberglass sector, as it is one of the major revenues generating sectors. Past studies showed that old conventional procedures are less productive in the growth of employees' creativity and retention of efficient staff. Due to uncertain and rapid changes in environment, firms need to reshape their business format, method and model to perform innovatively that helps in higher output of the organizations (Newman et al., 2018). Globalization accelerated organizations to reconstruct their business format through executing new HR practices and assemble motivated, committed \& quick-witted employees that promote innovational performance. Technological innovation among business environment is constantly growing the climate of organizations in multiple countries like Bahrain. Bahrain is confronting uncertain environmental conditions, instability and complications in business environment. In fact, Bahrain firms need to realize the innovational policy, climate unpredictability and inflexibilities to be globally competitive (Alzyoud \& Ogalo, 2020). According to Global Index 2019, Bahrain stands at 78 rank out of 128 countries in terms of innovational output. Past studies have signalized the significance of innovational performance development and found that Bahrain striving to overcome innovation challenges in the fiberglass industry, and main grounds of slighter performing firms are due to lack of knowledge, in-depth training, new technology and fierce skills (Hitt, 1998). Both private and public sectors come in the semi-government organization that integrates components of the establishment along with private organizations. The government has the competency to control its operations and specify eternal or semi-eternal employment that take advantage of government machinery and administrative functions are being controlled by establishment (Cooray et al., 2016). Innovational ideas has been experimented by employees of semi-state organizations since increased demand for transformation in pubic along with private sectors. Due to hierarchical nature, largely, government sectors are not in favor of buckle down new challenges and trends. Despite knowing globalized challenges, these organizations still executing old practices rather than implement a new innovative scheme (Ahmed et al., 2018).

The success of any organization highly depends on constructive practices of with a strategic approach. This asserts that organizations should take great care and concern for all the business functions with an eye for the long-term prospects. Particularly in today`s world, this has more meaning for business survival than anything else.

HRM and they act as triggered in achieving organizational objectives. Innovative, intellectual, smart and enthusiastic staff could attain objective and goals of any organization. In this modern era, skyscrapping performance of an organization highly depends on new HRM practices (Farouk et al., 2016). Intense competition among business showed that productive HRM is not any longer gratified and implemented with old traditional method (Kalleberg \& Moody, 1994), as past studies examined and found absence of advanced HRM procedures the viewpoint of economic advancement and absence of international and government HRM standards. Hence, to be competitive globally it is demanded to formulate new HRM practices and semi-state organizations must strategically implement NHRM practices to be competitive. Organization must have to formulate HR policies that are flexible in nature that can adapt according to business climate. The manufacturing sector of Bahrain is growing gradually, and sector of fiberglass are imparting from traditional methods to NHRM practices (Chuna et al., 2002).

NHRM practices has switched conventional methods to E-recruitment \&selection, reward \&incentives system, training \&development, mutual teamwork, investing in employee's health and engagement of employees in decision making that boosts up innovational performance (Farouk et al., 2016). 
Innovation performance can enhance by productive NHRM practices such as creativity in recruitment, holistic health benefits, talent acquisition, interviewing via video and fair evaluation system in terms of reward and incentives. Literature declares that by implementing better NHRM practices manufacturing sector can enhance the engagement of employees towards innovational approach (Ahmed et al., 2018). Previous studies found that organizational innovation could act as mediator for innovation in the performance of an organization (Urgal et al., 2013). Scholars have been very zealous to determine the impact of NHRM practices on IP with mediating effect of OP in the semi-state organization. Due to the cutthroat environment adoption of emerging technology is an especially stimulating factor in the growth of organization. In previous studies researchers has utilized various theories such as resource based view theory (Das \& Teng, 2000), human capital theory (Sweetland, 1996), the knowledge-based view (Eisenhardt \& Santos, 2002) to explain the connection among NHRM, IP and OP in semi-government organization. Additionally, researchers declared that TOE theory (technology organizational environment) mainly relate to the innovation performance that overall boost up capability, competency, and creativity of organization. TOE theory implementation helps organizations to achieve sustainable benefits of innovational strategies and NHRM practices could be valuable, high yielding and exceptional for performance of innovation and organizational innovation. So the current study has used TOE theory to evaluate the framework empirically that links the studied variables NHRM, IP and OP while on the other hand NHRM practices has importantly affected innovation performance especially in manufacturing sector of fiber glasses. Even so, literature has spotlighted less discussion on such topics, especially in the manufacturing sector of fiberglass. NHRM practices could stimulate the organizational performance in of fiberglass sector. Furthermore, NHRM practices and innovation performance have discussed less. Scholars highlighted that further exploration are required between NHRM practice and innovation performance for more powerful results. Therefore, this investigation contemplates as deep-seated issue and a qualified research gap that in state of need to be addressed. Thus, ongoing exploration empirically investigated the role of organization performance as mediator between NHRM and IP in fiberglass organization.

\section{Literature Review}

\subsection{Strategic Management}

The term strategic management denotes the process of objective specification by an organization to establish policies and procedures to plan and allocate necessary resources for effective achievement in the long run. Strategic management has critical significance when it comes to business functions and their performance. Overall, strategic management provides a direction to each of the business functions to assist managers and decision-makers in finalizing the courses of action. Strategic management is also referred as the highest level of decision-making activity that influences literally every aspect of the business (Pearce $e t$ al., 2000).

Strategic management is highly critical for organization to survive and this can only make considerable impact on their performance and responsive achievement of the objectives. Strategic management is an on-going process and it helps all departments and functional units of business to shape their plans and actions to ensure they are aligned with the broader business goals and strategies (Ansoff $e t$ al., 2018). This continuous process focuses on consistently formulating and implementing board plans, organizational policies, setting objectives and providing a blueprint to all the departments to make their objectives tactical and operational plans for responsive functioning. In this, there is constant evaluation and cross-examination as well which greatly facilitates in ensuring that the business functions are right on track.

Typically, strategic management goes with a comprehensive assessment of learning about an organization and its strategic position (Freeman, 2010). This aspect is concerned about the developments in the environment and the likely influence of these developments on the business at large. Here, the strategic management approach to any given business function plays a notable role in furthering its actions 
with a long-term perspective. Taken together, strategic management aids to every business function ranging from marketing to human resource management.

\subsection{Strategic Management of New HRM Practices and Innovation performance}

Innovation performance is critical for business these days, which is why it has been receiving considerable scholarly attention in the recent past as many studies are focusing on it these days (Hult et al., 2007). Therein, modification and restructuring of organizational strategies to manage the prompt transformation of innovational practices in organizations has increased much attention among researchers in past years. These rapid changes have forced firms to reshape their human resource practices and motivate employees to perform innovatory and give rise new powerful business environment. These NHRM practices are applying in different organizational processes like reward system, appraisal system, E-recruitment and selection, continual knowledge and Training and Development (Reeves \& Ford, 2004). New human resource practices affect the organizational strategies as identified by researchers in past studies. In order to adopt rapid changes of environment and challenges, researchers highlighted that organizations must have to implement new HR practices that are flexible in nature (MacDuffie, 1995) Higher productivity in the organization has embellished in developing along with developed economies. Human resource processes has always been great concern towards the success of any organization and be a factor in achieving organizational objectives. Moreover, new practices and procedures are triggers for innovational ideas that are acknowledged by management and employees (Alegre et al., 2013).

Innovative behavior of employees in terms of new human resource practices motivates innovation in organizations (Laursen, 2002). Past studies highlighted the importance of employee's performance with HRM processes and particularly NHRM practices could assist in high level of performance. Implementation of innovational design helps in building confidence of employees and leads towards innovational strategy in organization. NHRM practices provides assistance in achieving higher level of employees' commitment and ultimately enhance performance of organization. Effective HRM practices has great impact on innovation performance by encouraging employees (Prajogo \& Ahmed, 2006). Moreover, the researcher provided evidence that NHRM practices could heighten the inspiration \&competencies of employees and through the implementation of advancement in practices, firms can increase innovation in performance. Organizations practice new management style, technologies, the establishment of new products \&services and formulate organizational competencies to deal with firms' risk and challenges. Moreover, innovation in performance leads towards healthier performance and market share of the firms. In past investigations, researcher emphasized to develop competencies along with expertise to strengthen the employment relationships and encouraged innovation in performance. Semi state organizations gained competitive advantage through change in innovational technologies (Laursen, 2003).

$H_{I}$ : Strategic Management of New HRM practices are significantly related to Innovation Performance.

\subsection{New HRM practices and Organizational Innovation}

According to strategic HRM perspective NHRM practices are contemplate as significant in training and development of employees, skill development, competency behavior and creativity to achieve organizational innovation (Farouk et al., 2016). Additionally investigators have credence that NHRM practices signified the contribution of new reward \&compensation methods, T\&D, e-recruitment \&selection and innovation in performance explain personnel innovation in organizations (Waheed et al., 2019). Innovation in organizational environment are in state of need to be continuity in development of innovative working environment, training and development of employees, enhancing skills, talent and knowledge of employees, execution of practicality of technology advancement. Effective HRM practices assist organizations to be highly empowered, innovative, motivated, sense of accomplishment, teamwork and autonomy in decision-making (Kianto et al., 2017). For organizational magnification, NHRM practices 
plays considerable role as investigated in previous studies. However, organizational growth is related to NHRM practices such as E-recruitment and selection, compensation, and benefits, investing in health of employees, $\mathrm{T} \& \mathrm{D}$, reward system and employment relationships. The performance of organization must be higher if they practice new human resource practices. Past studies have a conception of NHRM practices but have no execution in their investigations. Continuity in innovation and employee commitment in manufacturing sector motivate firms to practice new HRM practices in large, medium and small organizations (Ceylan, 2013).

Therefore, current study purpose to examine the contribution of NHRM on innovation performance. Globally implementations of new technologies in manufacturing sector are significant part in achieving organizational objectives. NHRM practices, OI and IP are key factors in creating of new products, ideas, systems, competencies and technological ideas. Innovation in organization reflects new ideas, products, services and initiates latest use of technology that promotes innovational performance (Ahmed et al., 2020). Organizational innovation stimulates innovation in performance and contributes in sustaining competitive edge and advocacy of innovation at workplace helps in improving the performance and productivity of the firms.

Furthermore, OP is principally associated to four undertakings such as creative strategy, new manufacturing process and new development of product and growth of organization. Organizational innovation is considered a multi-tasked process containing. Implementation of new technology, ideas, strategies, methods and advancement in business processes promotes sense of accomplishment to employees and autonomy power of decisions also become more identified along with healthier employment relationships.

\section{$\mathrm{H}_{2}$ : Strategic Management of New HRM is positively related to organizational innovation}

\subsection{Organizational innovation and innovation Performance}

Innovation in organization is explained as execution of new ideas for improvement in business method, format, and procedure that boost up betterment of products, empower creativity, teamwork and promotes good employment relationships (Azar \& Ciabuschi, 2017). Innovation in organizations leads towards growth and continuation of innovation in performance. Newly changing technologies, heavy innovational competition, and more complexity in business processing, advancement in the process, new innovational practical implications, and creativity in manufacturing forced firms to formulate organizational innovatory strategy. In past examinations, researcher has discussed more about the old conventional methods of innovation in organization. Whereas according to other past studies related to organizational innovation if the organization not implement innovatory strategies and not prepare to adopt new ideas and trends in their processes than organizations will be less innovative and higher risk of slower growth that lead towards poor employer branding. To cope the market challenges and cut throat competition, manufacturing firms should have to implement new ideas in order to be competitive and dynamic. The innovational strategy is a comparatively new concept in the fiberglass sector of Bahrain. Innovation in performance refers to the implementation of new innovative ideas, methods and procedures. Innovation is procedure of practicing new process that enhances the performance of products and services (Prajogo \& Ahmed, 2006). Past studies revealed that adoption of innovational strategy lead the way towards formation of new expertise and competencies and firms use these latest ideas in their products and production system, reshaping their procedures, HR processes and way of dealing customer services.

Restructuring of new products, new production ways, effective information communication resources, better customer services, new technological methods to gain competitive advantage comes in the innovational concept. For organizational magnification, NHRM practices plays a considerable role as investigated in previous studies. However, organizational growth is related to NHRM practices such as E- 
recruitment and selection, compensation and benefits, investing in health of employees, $\mathrm{T} \& \mathrm{D}$, reward system and employment relationships. HR policies have huge role in the effectiveness and competitive advantage of the firms and most of the countries are striving hard to reshape their HR practices with new innovational HR scheme and Bahrain is one of them. Bahrain has been reshaping their business policies and transformed the old traditional procedures to latest practices in their fiberglass sector. Development and transformation in HRM practices leads towards innovational performance and higher productivity and these new (Shahzad et al., 2017).

\section{$\mathrm{H}_{3}$ : Organizational Innovation is significantly related to Innovation performance.}

\subsection{Mediating Role of Organizational Innovation}

Innovation in performance is fundamentally development in HR procedures, customer services, operations and methods of manufacturing and betterment in existing products and services (Zhou et al., 2013). Due to intense competition, external factors significantly affect to the performance of the organization and it could be overcome by pointing out significant skills and knowledge of employees that helps in enhancing business performance. Continuous innovation victoriously explains the expansion of existing services, technologies, policies and strategies of human resource management. It was significant to understand and determine the information by having the employee's knowledge about innovation strategies. Innovation in organization defines as creativity of new ideas, processes, techniques and operational processes that furnish firms with innovation in performance. Customers need fulfilled by the innovative organization and gain constructive outcomes and encourage staff to perform innovational, learn new skills, knowledge, technological invention and obtain higher recompense (Nouri, Ghorbani \& Soltani, 2017).

Innovation is one of the effective technological channels for achieving sustainable competitive advantage because continuity of innovation leads firms to higher level. According to Farouk et al. (2016) contribution of organizational innovation influenced the performance of organization in terms of flexibility in innovation. Current literature of the study supported the theoretical framework and found in previous investigations that organizational innovation indirectly strengthens the relationship between NHRM practices and innovation performance. Few studies demonstrated the contribution of innovation as a mediating role. Although past investigations have more focused on the effect of innovation on export performance (Yazhou \& Jian, 2013). In Bahrain, the manufacturing sector is enormously growing that needs to be in state if innovatory so that is the reason to conduct proper investigation to measure those factors that greatly influencing innovational performance. Therefore following hypothesis are formulated

$H_{4}$ : The association between Strategic Management of NHRM practices and Innovation Performance is mediated by Organizational Innovation.

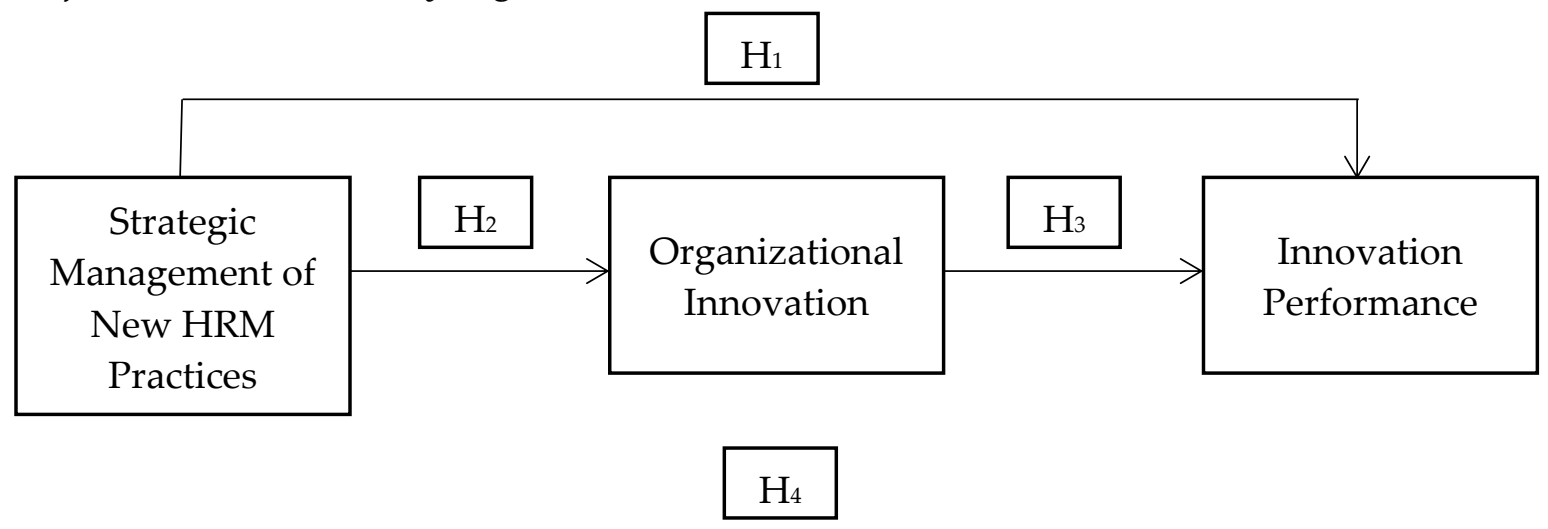

Figure 1: Framework of the Study 
Innovation in business is very critical (Ahmed, Mozammel \& Zaman, 2020; Ahmed et al., 2019). Studied literature has furnished with in depth understanding of theoretical framework to further explain the concept that innovation performance is enhanced and supported by NHRM practices in the manufacturing sector of fiberglass in Bahrain. Based on previous studies of HRM (Farouk et al., 2016) model of this study has formulated, and the structural model represents that NHRM practices and innovation performance is mediated by organizational innovation. The model of the present research is shown in Figure 1.

\section{Methodology}

\subsection{Population, Sampling, and Data Collection Procedure}

The objective of this study is to look over the effect of Strategic Management of NHRM practices on the innovation performance of Bahrain's fiberglass sector. The fiberglass sector was targeted and data were collected through questionnaires that were distributed and collected from mangers to represent the population of the entire targeted sector. To refrain from any errors, it is significant to have an appropriate sampling size. Calculate the appropriate sample size is very judgmental in research found by (Bartlett \& Higgins, 2001). Two sampling technique i.e convenient sampling technique and snowball sampling technique was used to open the door for smoothness of collected data as proposed by previous investigations. To test our research model, 3 measures of construct new human resource practices, organizational innovation and innovational performance were used to test the hypothesis of the study. Before distribution of questionnaires to the targeted population, the informal interview has taken from top as well as middle managers of the human resource department to confirm the soundness of questionnaire. An appeal was made to managers during the interview to identify any ambiguity, unknowing turn of phrase or any trouble in the understanding of questionnaires for refining in readability. So, the questionnaires were upgraded based on this recommendation and eventually distributed after approval from top management via proper email. Because of confidential matter, organization did not allow to personally collect data; thus, structured questionnaires were formulated, and the link of the survey was dispensed to employees by the human resource department via official email. Due to the error-free and high speed, online collection of data has recommended that was feasible for both researcher and respondents. Another reason of the online survey was the nature of employee's job as they were ineffective in responding during their long working hours. HR departments fully provided support for regulating good sense of communications with their respondents via official email and direct connection.

Questionnaires distributed among 1100 employees of fiberglass businesses in which 632 were authentic comeback in opposition to questionnaires that was distributed. The appeal was requested to point out the senior employees who had more knowledge and competency about the organizational research and development department because of the capability and proficiency of workers create more innovational reflection in organizations. Questionnaires comprised of two sections, one section contained demographic profile of the respondents (Managerial level, gender, marital status, education, age group, company name and period of employment in organization) whereas other section comprised of questions of studied variables strategic management of NHRM practices, innovational performance and organizational innovation. The demographic description is shown in Table 1.

Table 1: Demographic Profile

\begin{tabular}{ccc}
\hline Demographics & No. of Respondent & Percentage \\
\hline Gender & 370 & \\
Male & 242 & $58.3 \%$ \\
Female & 20 & $38.2 \%$ \\
Other & & $3.14 \%$ \\
\hline Marital Status & 378 & \\
Married & 254 & $60 \%$ \\
Single & & $40 \%$ \\
\hline
\end{tabular}




\begin{tabular}{|c|c|c|}
\hline Age Group & & \\
\hline $20-30$ & 238 & $38 \%$ \\
\hline $31-40$ & 155 & $24 \%$ \\
\hline $41-50$ & 112 & $18 \%$ \\
\hline $51-60$ & 69 & $11 \%$ \\
\hline Over 60 years & 58 & $9 \%$ \\
\hline \multicolumn{3}{|l|}{ Organizations } \\
\hline Awal & 147 & $23.3 \%$ \\
\hline CPIC & 230 & $36.4 \%$ \\
\hline Zarwan & 145 & $23 \%$ \\
\hline BFG & 110 & $17 \%$ \\
\hline \multicolumn{3}{|l|}{ Education } \\
\hline Intermediate & 90 & $14 \%$ \\
\hline Bachelor & 311 & $49.2 \%$ \\
\hline Post Graduate & 188 & $30 \%$ \\
\hline MPHIL & 38 & $6 \%$ \\
\hline $\mathrm{PhD}$ & 5 & $0.8 \%$ \\
\hline \multicolumn{3}{|c|}{ Managerial Level } \\
\hline Top level & 107 & $17 \%$ \\
\hline Middle Level & 208 & $33 \%$ \\
\hline Low level & 317 & $50 \%$ \\
\hline \multicolumn{3}{|c|}{ Tenure in Current } \\
\hline \multicolumn{3}{|c|}{ Organization } \\
\hline Less than 1 year & 55 & $9 \%$ \\
\hline $1-3$ years & 122 & $19 \%$ \\
\hline $4-7$ years & 177 & $28 \%$ \\
\hline 8-10years & 192 & $30 \%$ \\
\hline 11-15 Years & 86 & $14 \%$ \\
\hline
\end{tabular}

\subsection{Instrumentation}

All items were adapted from previous scales that were validated scales. As targeted population were quite educated and had good sense of understanding so the established questionnaires were in English that created easiness and quickness of response from respondents. Despite of this some employees had little ambiguity; thus, questionnaires were also translated into Urdu to facilitate the employees in better way to get effective results. Moreover, to get the better generalizability and content validity of the results, 5 employees were selected who had basic knowledge about innovational policies in organization along with 6 senior executives to examine the content validity. More filtration and assessment were fabricated based on this process of feedback.

\section{Analysis and Findings}

To examine the relationship among strategic management of NHRM practices, organizational innovation and innovation performance and to ensure the reliability of data researcher has used SPSS version 21.0 to determine the cause and effect relationship of latent variables. Linear regression analysis has done to predict the value of variable that is based on another variable. Relevant previous variables were eliminated as prerequisite demand of the study and then interchange variables were established by growing them. Likert scale had multiple questions that were determined by Cronbach's alpha, to test the authentication of the questionnaire, higher the value of alpha means higher the authentication of the factors that signalized the internal consistency of the questionnaire. All item values were greater than 0.8 that shows the favorability of internal consistency. Convergent validity is measured through factor loading of items. For Confirmatory Factor Analysis (CFA), values of the factor loadings need to be above 0.70 (Hair et al., 2017). In the case of exploratory research, it can be between 0.60 and 0.70 (Hair et al., 2017). Convergent validity of the constructs in the study was evaluated by AVE. Values of Average Variance Extracted (AVE) 
should be above 0.50 for every construct included in the study (Hair et al., 2017) and all values were above than 0.5 . Because of composite reliability, the convergent validity was significant with ratios between ratios 0.5 and 0.6 , thus confirming convergent validity. Discriminant validity measured through confirmatory efficacy and found that instrument contains higher discriminant validity. For validity of constructs and confirmatory factor analysis, software IBM AMOS 20 has used, and findings of model fitness showed the fitness of data as explained in Table 2. Model fitness has measured the contrast among many measurement models. Common bias method (CBM) occurs when data has collected through questionnaires and study was quantitative in nature so there was need to examine any variation in constructs that either might increase or decrease the chances of error. CBM conducted to estimate the relationship among theoretical constructs. For this common factor analysis (CFA) was performed to detect common method bias and CBM was detected by Harman's single factor analysis (Aguirre-Urreta \& Hu, 2019). However, findings of the study show that whom attribute values were greater than 1, represent $69.5 \%$ of absolute variance. Furthermore, measurement of CBM explained $14.06 \%$ of variance that is less than $50 \%$. Standard deviation, correlation and means of all 3 variables are pointed in table as follows.

Table 2: Loadings

\begin{tabular}{|c|c|c|}
\hline Construct & Items & Loadings \\
\hline \multirow{8}{*}{$\begin{array}{l}\text { Strategic Management of New } \\
\text { HRM }\end{array}$} & & Loadings \\
\hline & & \\
\hline & NHRM1 & 0.77 \\
\hline & NHRM2 & 0.64 \\
\hline & NHRM3 & 0.80 \\
\hline & NHRM4 & 0.84 \\
\hline & NHRM5 & 0.67 \\
\hline & NHRM6 & 0.72 \\
\hline Strategic Management of New & NHRM7 & 0.61 \\
\hline \multicolumn{3}{|l|}{ HRM Practices } \\
\hline \multirow[t]{9}{*}{ (NHRM) } & NHRM8 & 0.73 \\
\hline & NHRM9 & 0.62 \\
\hline & NHRM10 & 0.76 \\
\hline & NHRM11 & 0.81 \\
\hline & NHRM12 & 0.71 \\
\hline & NHRM13 & 0.65 \\
\hline & NHRM14 & 0.68 \\
\hline & NHRM15 & 0.77 \\
\hline & NHRM16 & 0.81 \\
\hline \multicolumn{3}{|l|}{ Innovation Performance } \\
\hline & IP1 & 0.76 \\
\hline & IP2 & 0.82 \\
\hline & IP3 & 0.80 \\
\hline & IP4 & 0.81 \\
\hline & IP5 & 0.77 \\
\hline & IP6 & 0.83 \\
\hline & IP7 & 0.84 \\
\hline \multicolumn{3}{|l|}{ Organizational Innovation } \\
\hline & OI1 & 0.72 \\
\hline & OI2 & 0.82 \\
\hline & OI3 & 0.75 \\
\hline & OI4 & 0.66 \\
\hline & OI5 & 0.60 \\
\hline & OI6 & 0.71 \\
\hline
\end{tabular}

Table 3: Descriptive Statistics, Reliability, and Correlations

\begin{tabular}{|c|c|c|c|c|c|c|c|c|c|c|c|c|c|}
\hline Var. & Mean & SD & 1 & 2 & 3 & 4 & 5 & 6 & 7 & 8 & 9 & 10 & 11 \\
\hline Gender & 0.69 & 0.48 & 1 & & & & & & & & & & \\
\hline Marital status & 2.07 & 0.57 & 0.18 & 1 & & & & & & & & & \\
\hline Age & 30.26 & 6.79 & $0.14^{* *}$ & 0.31 & 1 & & & & & & & & \\
\hline
\end{tabular}




\begin{tabular}{|c|c|c|c|c|c|c|c|c|c|c|c|c|c|}
\hline Semi-govt & & & 0.16 & 0.33 & 0.17 & & & & & & & & \\
\hline Organization & & & & & & 1 & & & & & & & \\
\hline Education & 3.047 & 0.69 & 0.04 & -0.27 & 0.12 & 0.06 & 1 & & & & & & \\
\hline $\begin{array}{l}\text { Managerial } \\
\text { Level }\end{array}$ & 1.90 & 0.51 & 0.05 & 0.16 & $-0.13^{*}$ & 0.11 & 0.14 & 1 & & & & & \\
\hline $\begin{array}{l}\text { Present Org. } \\
\text { Tenure }\end{array}$ & 5.07 & 4.47 & 0.12 & 0.15 & 0.15 & $\begin{array}{l}- \\
0.19^{* *}\end{array}$ & $0.81^{* *}$ & 0.15 & 1 & & & & \\
\hline NHRM & 5.02 & 0.66 & 0.05 & 0.07 & 0.07 & 0.12 & 0.04 & $0.21^{* *}$ & 0.18 & 1 & & & \\
\hline OI & 4.65 & 0.45 & 0.04 & 1 & 1 & 0.09 & -0.04 & -0.03 & 0.10 & $0.24^{* *}$ & 1 & & \\
\hline IP & 5.62 & 0.75 & $0.18^{*}$ & $0.13^{* *}$ & $0.13^{* *}$ & 0.20 & 0.15 & 0.11 & 0.14 & $0.12^{* *}$ & $0.20^{* *}$ & $0.28^{* *}$ & 1 \\
\hline
\end{tabular}

Findings showed that strategic management of NHRM was positively associated to innovation performance $\mathrm{p}<0.01, \mathrm{r}=0.13)$ and organizational innovation $(\mathrm{p}<0.01, \mathrm{r}=0.23)$. Both OI were IP are positively be in agreement and findings of both organization innovation and innovation in performance were positively corresponded $(\mathrm{p}<0.01, \mathrm{r}=0.20)$ that describing the true relationship among the studied variables. Path coefficient is a statistical multiple regression analysis that determines the cause and effect relationship and investigation signalized that new human resource practice was positively related to organizational performance, and this was advocated by H1. In table 5, regression analysis authentication is depicted. However, to measure the mediating role, this study has used Baron and Kenny (1986) technique for testing.

Table 4: Hierarchical Regression Analysis: Organizational Innovation and Innovation Performance

\begin{tabular}{lcccc}
\hline & \multicolumn{3}{c}{ Innovation Performance } & \multicolumn{2}{c}{ Organizational Innovation } \\
\cline { 2 - 5 } & M1 & M2 & M3 & M4 \\
\hline Gender & 0.04 & -0.07 & 0.04 & -0.02 \\
Marital status & 0.01 & 0.06 & 0.05 & 0.03 \\
Age & -0.10 & -0.09 & 0.08 & 0.02 \\
Semi government & & & & \\
Organizations & & & & 0.03 \\
Education & 0.10 & 0.06 & 0.09 & 0.05 \\
Managerial level & 0.12 & 0.08 & 0.04 & 0.02 \\
Present Org. Tenure & 0.09 & 0.11 & 0.07 & $0.26^{* * *}$ \\
NHRM & $0.19^{* * *}$ & & 0.03 & 0.33 \\
OI & & $0.23^{* * *}$ & $0.20^{* * *}$ & 0.25 \\
R2 & 0.23 & 0.27 & 0.19 & 0.08 \\
$\Delta$ R2 & 0.13 & 0.17 & & 0.03 \\
\hline
\end{tabular}

As stated by the test, the following four steps are required. In the first two courses of action, IV must have a significant association with DV and mediator. In step third, mediator should have significant association with the DV. The concluding step reveals that the influence of IV should be slight on DV when middleman incorporated. Findings of the investigation demonstrated that NHRM is highly noteworthy predictor of innovation performance $(\mathrm{p}<0.001 . \mathrm{b}=0.17)$; NHRM is highly noteworthy predictor of organizational innovation ( $\mathrm{p}<0.001, \mathrm{~b}=0.25)$; Organizational innovation is highly noteworthy predictor of innovation performance $(\mathrm{p}<0.001, \mathrm{~b}=0.22)$; and impact of NHRM practices transferred into insignificant $(b=0.03)$ when OI reverted simultaneously in between OP and NHRM practices that depicted complete effect of mediation. However fourth situation came as inconsistent because of less coefficient. In such manner to underpin the inconsistent situation, current study has observed the recommendations of previous investigations. Low coefficient of 0.02 were accepted according to (Huang et al., 2018)

\section{Discussion}

Strategic management of NHRM practices plays a tremendous contribution in innovational trends that have been followed by the fiberglass sector in Bahrain as well in rest of the world since many years. New human resource practice generates positive and beneficial effects on innovation performance and undoubtedly organizational innovation strengthens the relationship between NHRM practices and innovation performance in the context of the manufacturing sector in Bahrain. All tested hypothesis 
supports and strengthen the relationships among studied variables that were taken for empirically tested statistical analysis and all hypothesis out-turn positively supports the previous investigations. Result of the first hypothesis concluded that there is stronger relationship between NHRM practices and innovation performance which is in alignment with previous findings (Farouk et al., 2016). Organizational innovation was also found significant as mediator to help understand the association between strategic management of NHRM practices and IP in previous findings and this exploration-established evidence that OI is correspondingly beneficial in IT sector as well as an important role in manufacturing sectors. In this competitive era fiberglass sector must have to gain and sustain a competitive edge in terms of new human resource practices that leads towards innovation in the performance of employees together with organizational performance. Consequently, studied literature contributed positively to the impact of NHRM practices on innovational performance

\subsection{Theoretical Implications}

Framework of the current study is rooted on the strategic management of new HRM practices, innovation performance and organizational performance. To examine the connection between NHRM and IP, OP researcher has empirically tested the relationship through 632 responses in the manufacturing sector of fiberglass. Three significant implications: for better understanding, we have discussed deeply about the role of NHRM practices on innovation performance in the fiberglass sector. In past investigations, scholars contributed paid less heed to NHRM processes; neither focused on role NHRM practices nor studied the direct impact of NHRM practices on innovation performance. Due to globalized competition, firstly researcher has talked about the contribution and impact of New HRM practices performance of innovation in the fiberglass industry with the help of technology organization environment theory. Secondly, this study inaugurated organization innovation as negotiator between NHRM and innovation performance to look over effects of mediating contributor. Other perspective of this paper uncovered fact that without execution of new HRM practices fiberglass sector cannot nourish innovational attitude.

Hence, for stronger effect and outcome, organizational innovation can be considered as compulsory for growth and development of organizations. Considerably researcher has examined the direct effect of NHRM practices on IP along with the mediating effect of organizational performance. Eventually this investigation added up new consideration of strategic NHRM procedures on innovatory performance. We scrutinized that organizational performance boost up the relationship between NHRM and innovation performance and make connection positively stronger.

\subsection{Managerial Implications}

This study has implications for managers and policymakers. The findings suggest focusing on new human resource management practices with a strategic perspective to enhance innovation performance in the fiberglass sector in Bahrain. Upshots of organizational performance act as mediator between NHRM and innovation performance that helps to tackle new emerging technological challenges and trends. Organizational performance observes environmental threats in terms of resources and overcomes the uncertainties in demands. Managers should keep focused on gaining a competitive edge through new human resource measures for healthier innovational performance in the fiberglass sector to meet emerging challenges. Managers should understand the changing trends so it would be superior to find the newest mechanism of innovation performance. Furthermore, managers must have to ensure the implementation of NHRM practices in their organization, strive hard to encourage new expertise, talent, and competency and eliminate obstruction in way of success and enhance the working style of management. Consequently, to encourage employees, firms must have to execute NHRM practices so that they could perform higher and leads the organization to an optimum level. 


\section{Conclusion}

The current study shed light on the aspect of strategic management and how it can be of acute significance for the businesses large. Therein, the study attempted to investigate how strategic management of new HRM practices can help enhance innovation performance following the mediation or organizational innovation. The study has forwarded critical insights on the topic for scholars enthusiastic about strategic management of different organizational activities and initiatives.

\section{References}

Aguirre-Urreta, M. I., \& Hu, J. (2019). Detecting Common Method Bias: Performance of the Harman's Single-Factor Test. ACM SIGMIS Database: the DATABASE for Advances in Information Systems, 50(2), 45-70.

Ahmed, A., AlZgool, M. R. H., Abro, Z., Ahmed, U., \& Memon, U. (2019). Understanding the nexus of intellectual, social and psychological capital towards business innovation through critical insights from organizational culture. Humanities \& Social Sciences Reviews, 7(5), 1082-1086.

Ahmed, U., Mozammel, S., \& Zaman, F. (2020). Impact of Ecological Innovation, Entrepreneurial Self-Efficacy and Entrepreneurial Orientation on Environmental Performance and Energy Efficiency. International Journal of Energy Economics and Policy, 10(3), 289-295.

Ahmed, U., Shah, S. A., Qureshi, M. A., Shah, M. H., \& Khuwaja, F. M. (2018). Nurturing innovation performance through corporate entrepreneurship: The moderation of employee engagement. Studies in Business and Economics, 13(2), 20-30.

Alegre, J., Sengupta, K., \& Lapiedra, R. (2013). Knowledge management and innovation performance in a high-tech SMEs industry. International Small Business Journal, 31(4), 454-470.

Alzyoud, A. A. Y., Ogalo, H. S., \& ACDMHR, A. (2020). Strategic Management of Health and Safety at Work: Critical Insights for HR Professionals in the Construction Sector. Annals of Contemporary Developments in Management \& $H R(A C D M H R), 2(1), 42-48$.

Ansoff, H. I., Kipley, D., Lewis, A. O., Helm-Stevens, R., \& Ansoff, R. (2018). Implanting strategic management. Springer.

Azar, G., \& Ciabuschi, F. (2017). Organizational innovation, technological innovation, and export performance: The effects of innovation radicalness and extensiveness. International Business Review, 26(2), 324-336.

Barney, J. B., \& Hesterly, W. S. (2009). Strategic management and competitive advantage. Upper Saddle River, NJ: Pearson Education.

Baron, R. M., \& Kenny, D. A. (1986). The moderator-mediator variable distinction in social psychological research: Conceptual, strategic, and statistical considerations. Journal of Personality and Social Psychology, 51(6), 1173.

Bartlett, J. E. (2001). II, Kotrlik, JW, \& Higgins, CC (2001). Organizational research: Determining appropriate sample size in survey research. Information Technology, Learning, and Performance Journal, 19(1), 43-50.

Ceylan, C. (2013). Commitment-based HR practices, different types of innovation activities and firm innovation performance. The International Journal of Human Resource Management, 24(1), 208-226.

Cooray, A., Dutta, N., \& Mallick, S. (2016). Does female human capital formation matter for the income effect of remittances? Evidence from developing countries. Oxford Development Studies, 44(4), 458-478.

Cunha, R. C., Pina e Cunha, M., Morgado, A., \& Brewster, C. (2002). Market forces, strategic management, HRM practices and organizational performance, A model based in a European sample. Management Research, 1(1), 7991.

Das, T. K., \& Teng, B. S. (2000). A resource-based theory of strategic alliances. Journal of management, 26(1), 31-61.

Eisenhardt, K. M., \& Santos, F. M. (2002). Knowledge-based view: A new theory of strategy. Handbook of strategy and management, 1(1), 139-164.

Farouk, S., Abu Elanain, H. M., Obeidat, S. M., \& Al-Nahyan, M. (2016). HRM practices and organizational performance in the UAE banking sector: The mediating role of organizational innovation. International Journal of Productivity and Performance Management.

Freeman, R. E. (2010). Strategic management: A stakeholder approach. Cambridge university press.

Hair, J. F., Hult, G. T. M., Ringle, C. M., Sarstedt, M., \& Thiele, K. O. (2017). Mirror, mirror on the wall: a comparative evaluation of composite-based structural equation modeling methods. Journal of the Academy of Marketing Science, 45(5), 616-632.

Hitt, M. A. (1998). Twenty-first-century organizations: Business firms, business schools, and the academy. Academy of 
Management Review, 23(2), 218-224.

Hult, G. T. M., Ketchen, D. J., \& Arrfelt, M. (2007). Strategic supply chain management: Improving performance through a culture of competitiveness and knowledge development. Strategic management journal, 28(10), 1035-1052.

Kalleberg, A. L., \& Moody, J. W. (1994). Human resource management and organizational performance. American behavioral scientist, 37(7), 948-962.

Kianto, A., Sáenz, J., \& Aramburu, N. (2017). Knowledge-based human resource management practices, intellectual capital and innovation. Journal of Business Research, 81, 11-20.

Laursen, K. (2002). The importance of sectoral differences in the application of complementary HRM practices for innovation performance. International Journal of the Economics of Business, 9(1), 139-156.

Laursen, K., \& Foss, N. J. (2003). New human resource management practices, complementarities and the impact on innovation performance. Cambridge Journal of Economics, 27(2), 243-263.

MacDuffie, J. P. (1995). Human resource bundles and manufacturing performance: Organizational logic and flexible production systems in the world auto industry. Ilr Review, 48(2), 197-221.

Newman, A., Nielsen, I., Smyth, R., \& Hirst, G. (2018). Mediating role of Psychological capital in the relationship between social support and wellbeing of refugees. International Migration, 56(2), 117-132.

Nouri, B. A., Ghorbani, R., \& Soltani, M. (2017). The effect of knowledge management on organizational innovation with the mediating role of organizational learning (case study: Agricultural Bank in Iran). Journal of Applied Economics and Business Research JAEBR, 7(3), 194-211.

Park, J., Díaz-Posada, N., \& Mejía-Dugand, S. (2018). Challenges in implementing the extended producer responsibility in an emerging economy: The end-of-life tire management in Colombia. Journal of Cleaner Production, 189, 754-762.

Pearce, J. A., Robinson, R. B., \& Subramanian, R. (2000). Strategic management: Formulation, implementation, and control. Columbus, OH: Irwin/McGraw-Hill.

Prajogo, D. I., \& Ahmed, P. K. (2006). Relationships between innovation stimulus, innovation capacity, and innovation performance. RED Management, 36(5), 499-515.

Reeves, T. C., \& Ford, E. W. (2004). Strategic management and performance differences: Nonprofit versus for-profit health organizations. Health care management review, 29(4), 298-308.

Shahzad, F., Xiu, G., \& Shahbaz, M. (2017). Organizational culture and innovation performance in Pakistan's software industry. Technology in Society, 51, 66-73.

Sweetland, S. R. (1996). Human capital theory: Foundations of a field of inquiry. Review of Educational Research, 66(3), 341-359.

Urgal, B., Quintás, M. A., \& Arévalo-Tomé, R. (2013). Knowledge resources and innovation performance: the mediation of innovation capability moderated by management commitment. Technology Analysis $\mathcal{E}$ Strategic Management, 25(5), 543-565.

Waheed, A., Miao, X., Waheed, S., Ahmad, N., \& Majeed, A. (2019). How new HRM practices, organizational innovation, and innovative climate affect the innovation performance in the IT industry: A moderated-mediation analysis. Sustainability, 11(3), 621.

Yazhou, W. A. N. G., \& Jian, L. I. N. (2013). An empirical research on knowledge management orientation and organizational performance: the mediating role of organizational innovation. African Journal of Business Management, 7(8), 604-612.

Zhou, Y., Hong, Y., \& Liu, J. (2013). Internal commitment or external collaboration? The impact of human resource management systems on firm innovation and performance. Human Resource Management, 52(2), 263-288.

(C) 2020 by the author(s). Published by Annals of Contemporary Developments in Management \& HR (ACDMHR), under the terms and conditions of the Creative Commons Attribution (CC BY) license which can be accessed at http://creativecommons.org/licenses/by/4.0. 